\title{
Analysis of large-volume DNA markers and polymerase chain reaction products by capillary electrophoresis in the presence of electroosmotic flow
}

\author{
Wei-Lung Tseng, Ming-Mu Hsieh, Shang-Ji Wang, Chih-Ching Huang, Yu-Cheng Lin, \\ Po-Ling Chang, Huan-Tsung Chang* \\ Department of Chemistry, National Taiwan University, Roosevelt Road, Sec. 4, Taipei 106, Taiwan
}

Received 20 April 2001; received in revised form 11 July 2001; accepted 12 July 2001

\begin{abstract}
We have demonstrated on-line concentration and separation of DNA in the presence of electroosmotic flow (EOF) using poly(ethylene oxide) (PEO) solutions. After injecting large-volumes DNA samples, PEO solutions entered a capillary filled with $400 \mathrm{~m} M$ Tris-borate (TB) buffers by EOF and acted as sieving matrices. DNA fragments stacked between the sample zone and PEO solutions. Because sample matrixes affected PEO adsorption on the capillary wall, leading to changes in EOF, migration time, concentration, and resolving power varied with the injection length. When injecting $\Phi X 174$ RF DNA-HaeIII digest prepared in $5 \mathrm{~m} M$ Tris- $\mathrm{HCl}$ buffer, $\mathrm{pH} 7.0$, at $250 \mathrm{~V} / \mathrm{cm}$, peak height increased linearly as a function of injection volume up to $0.9 \mu \mathrm{l}$ (injection time $150 \mathrm{~s}$ ). The sensitivity improvement was 100 -fold compare to that injected at $25 \mathrm{~V} / \mathrm{cm}$ for $10 \mathrm{~s}(0.006 \mu \mathrm{l})$. When injecting $1.54 \mu \mathrm{l}$ of GeneScan $1000 \mathrm{ROX}$, the sensitivity improvement was 265 -fold. The sensitivity improvement was 40-fold when injecting $0.17 \mu \mathrm{l}$ DNA sample containing pBR 322/Hae III, pBR 328/BglI, and pBR 328/HinfI digests prepared in phosphate-buffered saline. This method allows the analysis of polymerase chain reaction (PCR) products amplified after 17 cycles when injecting $0.32 \mu \mathrm{l}$ (at $30 \mathrm{~cm}$ height for $300 \mathrm{~s}$ ). The total analysis time was shorter (91.6 min) than that (119.6 min) obtained from injecting PCR products after 32 cycles for $10 \mathrm{~s}$. () 2001 Published by Elsevier Science B.V.
\end{abstract}

Keywords: Sample stacking; DNA; poly(ethylene oxide)

\section{Introduction}

Over the last few years, capillary electrophoresis (CE) has emerged as an important technique for the rapid and effective separation of DNA [1-6]. For analysis of less than micromolar concentrations of DNA, sensitive detection methods like laser-induced fluorescence (LIF) are needed in CE [7-10]. Al-

*Corresponding author. Tel./fax: +886-22-362-1963.

E-mail address: changht@mail.ch.ntu.edu.tw (H.-T. Chang). though it is sensitive for routine analysis, CE-LIF associated with special techniques, such as counting the fluorescence burst by confocal microscopy, are sometimes employed for DNA sequences and single molecules [11,12].

To improve the sensitivity in $\mathrm{CE}$, a number of on-line electrophoretic concentration techniques that are easily performed in most laboratories have been developed. Isotachophoretic (ITP) preconcentration has been applied to concentrate about 20-50\% capillary volumes of DNA samples [13-15]. To 
maintain high-resolving power, the sample volume (injection length) is limited [16]. Field amplification in CE easily provides at least 100-fold improvement in detection of analytes and has been widely accepted as a useful concentration technique [17-22]. When the sample matrix has a low conductivity (usually a diluted buffer or water) than that of the buffers filled in the capillary, a relatively high electric field distributes across the sample zone. Consequently, analytes within the sample zone are accelerated with a higher local velocity and stack at the boundary of the buffer zone, in which their velocities are low. For example, a method of injecting a water plug prior to sample injection to create low electric field strengths at the beginning of the separation has been demonstrated for loading large volumes of samples and obtaining sharper peaks [23].

One common problem found is that the concentration factors of ITP and field amplification are poor when high ionic strengths of samples [24] such as polymerase chain reaction (PCR) product are analyzed. Although salts can be removed by precipitating DNA samples with cold ethanol [25] or chromatography [26], these methods are not suitable for high-throughput DNA analysis because of timeconsuming and laborious procedures. In principle, the conductivity of the sample zone can be reduced if the matrix is titrated by acids or bases under weakly acidic or alkaline conditions, resulting in a highly focusing electric field at the titration area and in turn stacking dilute samples. For example, the conductivity of DNA samples [prepared in a buffer containing tris(hydroxymethyl)aminomethane (Tris) cations] decreased when the Tris cations were titrated by hydroxide ions [27]. Only minor loss of resolution observed when DNA samples were injected at $50 \mathrm{~V} / \mathrm{cm}$ for $360 \mathrm{~s}$. Because of loss of resolution by a shorter separation length and increases in band broadening at low electric fields when injecting large volumes of DNA samples, the sensitivity improvement was only about 15 -fold. More recently, a similar idea by using a microporous membranemediated loading has been developed for ultrathin slab gel electrophoresis [28]. The DNA molecules stack up against the higher-conductivity sieving matrices at the interface of the separation gel.

So far, deactivated capillaries are commonly used for DNA concentration and separation in CE in order to minimize the variation of electroosmotic flow (EOF) and the interaction with DNA that leads to irreproducibility and poor resolution [29,30]. In contrast, we have developed DNA separations in the presence of EOF using bare fused-silica capillaries [31-33]. DNA fragments migrated against EOF and thus back into the poly(ethylene oxide) (PEO) solutions, wherein the DNA was separated according to sieving mechanism. Thus, large DNA fragments were detected earlier at the cathode end. To obtain run-to-run reproducibility (RSD of the $\mathrm{EOF}<2.0 \%$ ), washing the capillary wall with $0.5 \mathrm{M} \mathrm{NaOH}$ at 25 $\mathrm{V} / \mathrm{cm}$ for $10 \mathrm{~min}$ between runs is suggested when PEO solutions are used. More recently, we also found that PEO adsorption on the capillary wall during separations was small when the capillary was filled with high ionic strengths of buffers, such as $400 \mathrm{~m} M$ Tris-borate (TB) buffers [34].

In our previous studies, we have shown that DNA and proteins stack at the boundary between the sample zone and PEO [35,36]. Although more than 66- and 1000-fold sensitivity improvement has been demonstrated for DNA and protein samples prepared in low-conductivity media, respectively, this method still has shortages when analyzing high-conductivity samples, presumably because of Joule heating and greater differences in electric field strengths among TB buffer, sample, and PEO solution. The use of low-concentration of TB buffers to fill and prepare PEO solutions also causes problems, such as poor reproducibility and peak broadening, when injecting a large-volume of samples. In this paper, we described a modified method allowing analysis of lowconductivity and high-conductivity DNA markers as well as PCR products.

\section{Materials and methods}

\subsection{Equipment}

The basic design of the separation system has been previously described [31]. Briefly, a high-voltage power supply (Gamma High Voltage Research, Ormond Beach, FL, USA) was used to drive electrophoresis. The entire detection system was enclosed in a black box with a high-voltage interlock. High- 
voltage end of the separation system was put in a laboratory-made plexiglass box for safety. A $1.5-\mathrm{mW}$ $\mathrm{He}-\mathrm{Ne}$ laser with $543.6 \mathrm{~nm}$ output from Melles Griot (Irvine, CA, USA) was used for excitation. The light was collected with a $10 \times$ objective (numeric aperture $=0.25$ ). One RG 610 cutoff filter was used to block scattered light before the emitted light reaches the photomultiplier tube (Hamamatsu R928). The amplified currents were transferred directly through a $10-\mathrm{k} \Omega$ resistor to a 24-bit A/D interface at $10 \mathrm{~Hz}$ (Borwin, JMBS Developments, Le Fontanil, France) and stored in a personal computer. Capillaries (Polymicro Technologies, Phoenix, AZ, USA), $75 \mu \mathrm{m}$ I.D. $\times 365 \mu \mathrm{m}$ O.D., were used for DNA separations without any further coating process. The capillary lengths were either $60 \mathrm{~cm}(50 \mathrm{~cm}$ effective length) or $40 \mathrm{~cm}$ (30 cm effective length)

\subsection{Materials}

PEO with molecular mass 8000000 and other chemicals for preparing buffer solutions were from Aldrich (Milwaukee, WI, USA). Ethidium bromide (EtBr) was obtained from Molecular Probes (Eugene, OR, USA). Please note that wearing gloves when handling EtBr is required because it is a highly carcinogenic compound. In order to minimize Joule heat generated at high electric field strengths, EDTA that was commonly added to prevent digestion of DNA by enzymes was not added in the buffers used in this study. TB buffers prepared from Tris were adjusted with boric acid to $\mathrm{pH} 10.0$ and 9.0, respectively. Unless otherwise noted, a $x \mathrm{~m} M$ (e.g. 400 $\mathrm{m} M$ ) TB buffer herein means a buffer containing $x$ $\mathrm{m} M$ (e.g. $400 \mathrm{~m} M$ ) Tris adjusted with suitable amounts of boric acid. Phosphate-buffered saline (PBS) was prepared by dissolving $8.0 \mathrm{~g}$ of $\mathrm{NaCl}, 0.2$ $\mathrm{g}$ of $\mathrm{KH}_{2} \mathrm{PO}_{4}, 0.46 \mathrm{~g}$ of $\mathrm{Na}_{2} \mathrm{HPO}_{4}$, and $0.2 \mathrm{~g}$ of $\mathrm{KCl}$ in 11 of water, $\mathrm{pH}$ 7.4. PEO solutions were prepared from the TB buffers containing $5 \mu \mathrm{g} / \mathrm{ml} \mathrm{EtBr}$, respectively. ФX174 RF DNA-HaeIII digest (500 $\mu \mathrm{g} / \mathrm{ml}$ ) was purchased from Pharmacia Biotech (Uppsala, Sweden). DNA markers V (pBR 322/ HaeIII digest) $(250 \mu \mathrm{g} / \mathrm{ml})$ and VI (pBR 328/BglI digest and pBR 328/HinfI digest) $(250 \mu \mathrm{g} / \mathrm{ml})$ were from Boehringer Mannheim (Mannheim, Germany). The DNA sample containing markers V and VI used in this study was prepared by mixing equal volume of the two DNA markers. GeneScan 1000 ROX (8 $\mathrm{n} M$ ) was purchased from Perkin-Elmer (Foster City, CA, USA). Herein, GeneScan 1000 ROX was diluted 100-fold with $25 \mathrm{~m} M$ TB buffers, pH 10.0. QIAamp DNA blood mini kit was purchased from Qiagen (Hilden, Germany). PCR kits were obtained from Promega (Madison, WI, USA).

\subsection{Preparation of PEO solutions}

Certain amounts of PEO were gradually added into the TB buffer, $\mathrm{pH} 9.0$, in a beaker stirring in a water bath at $85-90^{\circ} \mathrm{C}$. During the addition of PEO, a magnetic stirring rod was used at high speed to produce a well homogeneous suspension. After addition was complete, the suspension was stirred for at least one more hour. Finally, polymer solutions were degassed with a vacuum system in an ultrasonic tank. Polymer solutions stored in a refrigerator at $4^{\circ} \mathrm{C}$ were usable for at least 3 days.

\subsection{Stacking and separation}

Prior to analysis, capillaries were treated with 0.5 $M \mathrm{NaOH}$ overnight. After each run, capillaries were washed with $0.5 \mathrm{M} \mathrm{NaOH}$ at $25 \mathrm{~V} / \mathrm{cm}$ for $10 \mathrm{~min}$ to remove polymer solutions and refresh the capillary wall. DNA samples were injected into the capillary filled with TB buffers at 25 or $250 \mathrm{~V} / \mathrm{cm}$ for certain times. The sample volume was calculated from the capillary radius and the injection length that was determined by monitoring the baseline shift at several detection windows during sample injection. During the separation, PEO solution entered the capillary by EOF and acted as sieving matrices.

\subsection{DNA extraction}

The blood sample was from a normal male. Human genomic DNA from buffy coat was extracted using the QIAamp DNA blood mini kit in accordance with manufacturer's instructions.

\subsection{PCR products}

Amplification of the DNA sample was conducted as suggested by the manufacturers. Briefly, $22.5 \mu \mathrm{l}$ 
PCR master mix component was prepared by mixing $17.45 \mu \mathrm{l}$ sterile water, $2.50 \mu \mathrm{l}$ STR $10 \times$ buffer, $2.50 \mu \mathrm{l}$ TH01 $10 \times$ primer pairs $\left(5^{\prime}-\right.$ GTGGGCTGAAAAGCTCCCGATTAT- $3^{\prime}$ and $5^{\prime}-$ ATTCAAAGGGTATCTGGGCTCTGG- $3^{\prime}$ ), and 0.05 $\mu \mathrm{l} \mathrm{Taq}$ polymerase $(5 \mathrm{U} / \mu \mathrm{l})$. To the PCR master mix, $2.5 \mu \mathrm{l}$ of human genomic DNA (25 ng) was added. PCR was conducted as: initial incubation at $96^{\circ} \mathrm{C}$ for $2 \mathrm{~min}$; cycling for first 10 cycles at $94^{\circ} \mathrm{C}$ for $1 \mathrm{~min}$, at $64^{\circ} \mathrm{C}$ for $1 \mathrm{~min}$, and at $70^{\circ} \mathrm{C}$ for $1.5 \mathrm{~min}$; and cycling for the last 7 and 22 cycles, respectively, at $90^{\circ} \mathrm{C}$ for $1 \mathrm{~min}$, at $64^{\circ} \mathrm{C}$ for $1 \mathrm{~min}$, and at $70^{\circ} \mathrm{C}$ for $1.5 \mathrm{~min}$.

\section{Results and discussion}

\subsection{Stacking evolution}

Since PEO adsorption on the capillary wall is marked at low ionic strengths, leading to decrease in EOF and irreproducible results, injection of a long plug of DNA sample prepared in water is not proper. In this study, $5 \mathrm{~m} M$ Tris- $\mathrm{HCl}$ buffers, $\mathrm{pH}$ 7.0, PBS, or $25 \mathrm{~m} M$ TB buffer, $\mathrm{pH} 10.0$, were used to prepare DNA samples. As suggested in our previous study, reproducibility and resolution were optimized when using a capillary filled with high-concentration TB buffer [34]. In order to allow injection of a large volume of DNA sample prepared in low or highconductivity media, the capillaries were filled with $400 \mathrm{~m} M$ TB buffers, $\mathrm{pH} 10.0$, and PEO solutions were prepared in either 100 or $200 \mathrm{~m} M \mathrm{~TB}, \mathrm{pH} 9.0$. To clearly show evolution of concentration and separation, Fig. 1 was depicted. With negative charges, DNA fragments migrated against EOF and entered PEO (neutral) solution, wherein their electrophoretic mobilities decreased mainly due to increases in viscosity and sieving. As a result, the DNA fragments stacked at the boundary between the sample zone and PEO. Because large DNA fragments migrated slowly against EOF in PEO matrices, the large ones were detected earlier at the cathode end.

$\mathbf{A}$

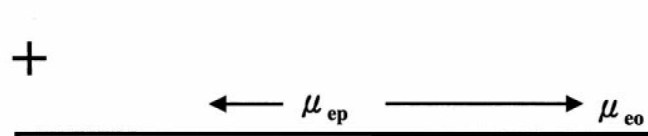

\section{Detection}
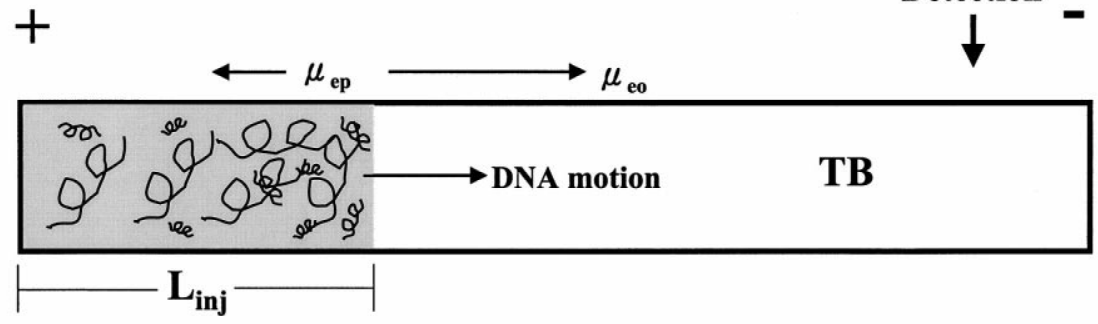

B

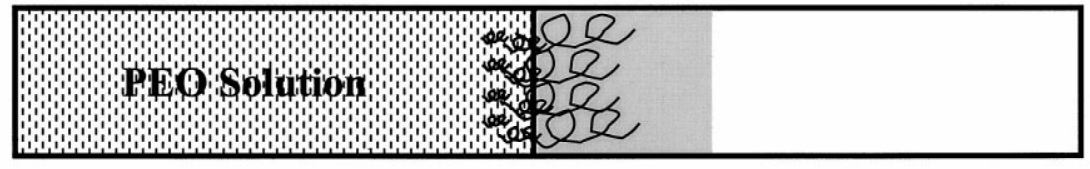

C

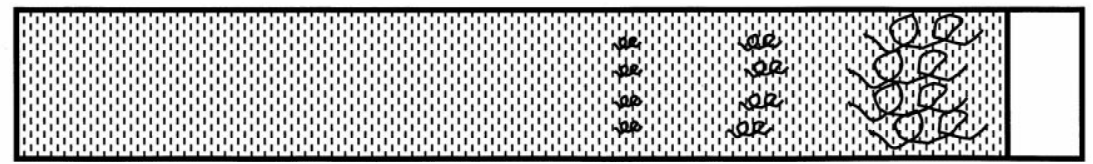

Fig. 1. Evolution of analyte zones in the separation of DNA under stacking conditions. (A) A plug of DNA sample was injected to the capillary filled with a $400 \mathrm{~m} M$ TB buffer. (B) PEO solutions containing $5 \mu \mathrm{g} / \mathrm{ml} \mathrm{EtBr}$ from the anodic vial entered the capillary by EOF and the DNA fragments were subjected to stacking when migrating into the PEO solution. (C) Separation of the stacked DNA was based on the sieving mechanism in CE. $L_{\mathrm{inj}}, \mu_{\mathrm{eo}}$, and $\mu_{\mathrm{ep}}$ represents the injection length, the EOF mobility and the electrophoretic mobilities of the DNA fragments, respectively. 


\subsection{Stacking efficiency}

The separation length, which relies on the injection length and the relative migration mobility of the concentrated DNA fragments and PEO matrices, is important for optimizing resolution. The longer the injection length, the greater distance between the two ends of the sample zones is, resulting in a shorter separation length. On the other hand, the separation length for concentrated DNA fragments is greater when PEO migrates much faster than DNA fragments. In other words, the small concentrated DNA fragment has a greater separation length. The electropherograms in Fig. 2A show the separation of DNA fragments injected at $25 \mathrm{~V} / \mathrm{cm}$ for $10 \mathrm{~s}$ (in the upper panel) and at $250 \mathrm{~V} / \mathrm{cm}$ for $150 \mathrm{~s}$, respectively. The limit of detection for the DNA sample was $10.0 \mathrm{pg} / \mu \mathrm{l}$ [signal-to-noise ratio $(S / N)=3$ based on the peak height corresponding to the 72-base pair (bp) fragment] when injecting at $250 \mathrm{~V} / \mathrm{cm}$ for 150 s. The improvement in sensitivity was about 100 -fold compared to that obtained when injecting at $25 \mathrm{~V} / \mathrm{cm}$ for $10 \mathrm{~s}(0.006 \mu \mathrm{l})$. Because of slight increases in the bulk EOF during the injection of DNA sample (lower ionic strengths) and decreases in the bulk EOF during the separation, the injected volume could not be precisely calculated from the migration times shown in Fig. 2A. In order to estimate the injection volume, the detection windows at different places of the capillary were created for observing the DNA zones during injections at $250 \mathrm{~V} / \mathrm{cm}$ for different times (data not shown). The estimated injection length at $250 \mathrm{~V} / \mathrm{cm}$ for $150 \mathrm{~s}$ was about 20 $\mathrm{cm}$, corresponding to $0.9 \mu \mathrm{l}$.

The peak heights for all DNA fragments were proportional to injection volumes from 0.006 to 0.9 $\mu \mathrm{l}$, with linear regression $\left(R^{2}\right)$ values ranging from 0.930 to 0.995 . For example, $R^{2}$ values of the two linear plots corresponding to the 603- and 118-bp fragments shown in Fig. 2B were 0.995 and 0.930, respectively. The result of a steeper plot corresponding to the 603-bp fragment is due to the extra amount of intercalators complexed. Fig. 2C shows that widths at half the net peak height for all peaks were less than $1.2 \mathrm{~s}$ and kept fairly constant, suggesting that all the DNA fragments stacked. As a result of decreases in EOF with increasing the injection length, the peaks corresponding to the small
DNA fragments became wider. Thus slight variations of the peak width due to diffusion were possible if a longer sample plug was injected. The problem was more serious when injecting DNA prepared in 10 $\mathrm{m} M \quad N$-(2-acetamido)-2-aminoethanesulfonic acid ( $\left.\mathrm{p} K_{\mathrm{a}}=6.8\right), \mathrm{pH} 7.0$ (adjusted with Tris), because of more pronounced PEO adsorption. As a result, the injection time was limited to less than $50 \mathrm{~s}$ (result not shown). Moreover, the peaks corresponding to the DNA fragments when injecting for $30 \mathrm{~s}$ were wider compared to that shown in Fig. 2A, suggesting that $\mathrm{pH}$ changes should contribute for DNA stacking.

\subsection{Resolution}

As soon as PEO solutions (more viscous) entered the capillary filled with $400 \mathrm{~m} M$ TB buffer, the bulk EOF mobility decreased. The decreases in bulk EOF were related to the fractions of local EOF mobilities of the capillary filled with PEO solutions and TB buffers [17,37]. In addition to the viscosity dependence, the bulk EOF decreased as a result of PEO adsorption. PEO adsorption increased with increasing the plug length of low-conductivity DNA samples. Consequently, the migration times increased with increasing the injection length (volume) shown in Table 1. Although, the bulk EOF temporarily decreased, the RSD values for the bulk EOF were less than $2.0 \%$, indicating that the adsorbed PEO molecules were easily removed by washing with 0.5 $M \mathrm{NaOH}$ at $25 \mathrm{~V} / \mathrm{cm}$ for $10 \mathrm{~min}$ prior to sample injections. This is likely due to decreases in hydrogen bonding between PEO molecules and the capillary wall at high $\mathrm{pH}$ and in presence of greater amounts of sodium ions.

\subsection{DNA in high-conductivity media}

It has been known that electrokinetic injection is biased toward high electrophoretic mobility ions, such as chlorides, relative to the DNA fragments $[38,39]$. The separation of large-volumes DNA sample prepared in high-conductivity media could be problematic (poor resolution and irreproducibility) because of excessive Joule heat generated at high electric field strengths. Besides, DNA prepared in high-conductivity media could not stack effectively when conventional on-line concentration techniques 

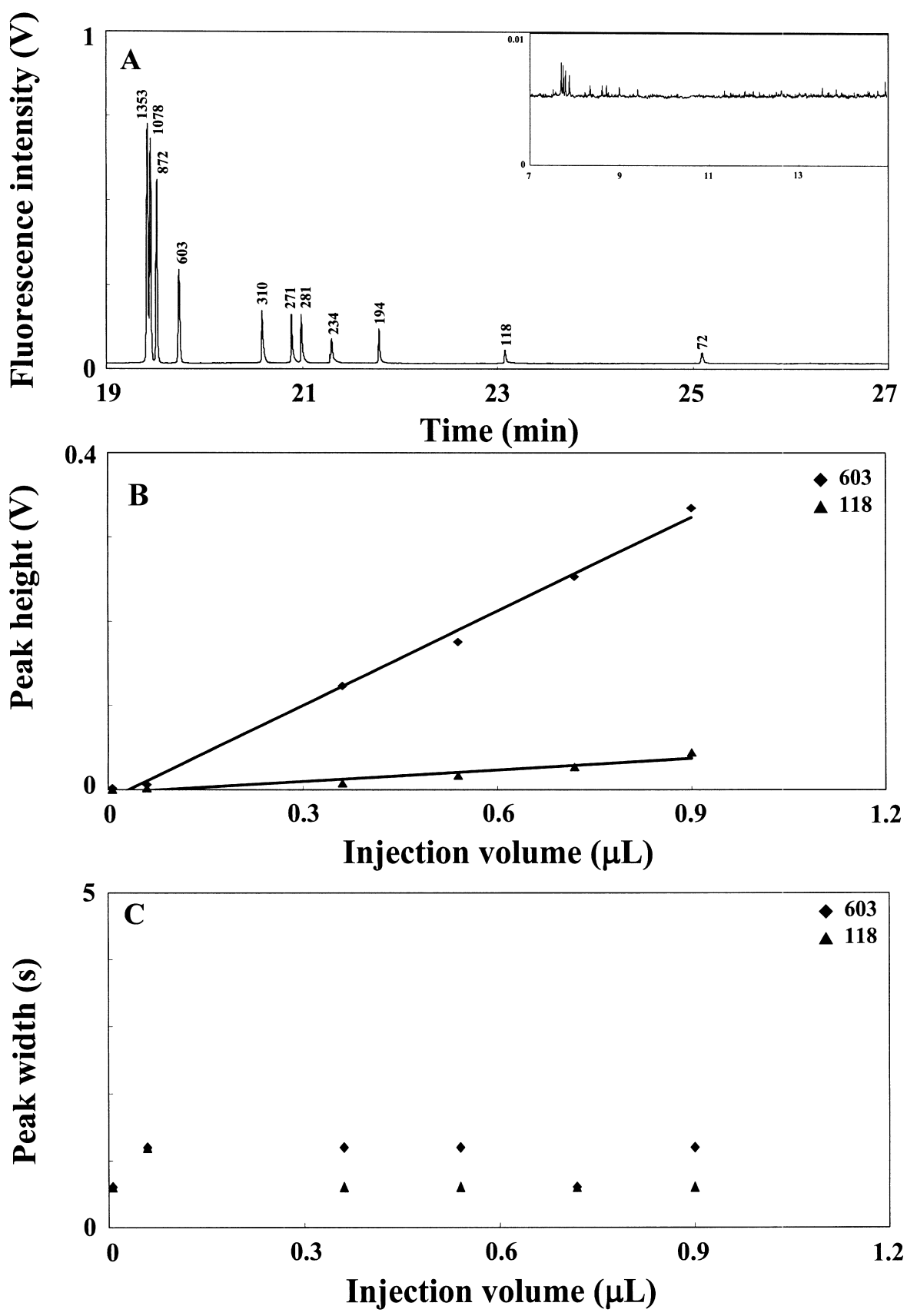

Fig. 2. Effect of the injection length on separation of $100 \mathrm{pg} / \mu \mathrm{l} \Phi \mathrm{X} 174 \mathrm{RF}$ DNA-HaeIII digest in the presence of the EOF at $375 \mathrm{~V} / \mathrm{cm}$ using 2.0\% PEO solutions prepared in $100 \mathrm{~m} M$ TB solutions, $\mathrm{pH} 9.0$, containing $5 \mu \mathrm{g} / \mathrm{ml} \mathrm{EtBr}$. Capillary: $40 \mathrm{~cm}$ (30 cm effective length), filled with a $400 \mathrm{~m} M \mathrm{~TB}, \mathrm{pH}$ 10.0. (A) Injection volume: 0.9 and $0.006 \mu \mathrm{l}$ (upper panel), (B) peak height against injection volume, (C) peak width against injection volume. 
Table 1

Effect of injection length on resolution and separation window in the presence of the EOF

\begin{tabular}{|c|c|c|c|c|c|c|c|c|c|c|c|}
\hline \multirow[t]{2}{*}{ Injection } & \multicolumn{10}{|l|}{ Resolution } & \multirow{2}{*}{$\begin{array}{l}\text { Separation } \\
\text { window (min) }\end{array}$} \\
\hline & $1353 / 1078$ & $1078 / 872$ & $872 / 603$ & $603 / 310$ & $310 / 271$ & $271 / 281$ & $281 / 234$ & $234 / 194$ & $194 / 118$ & $118 / 72$ & \\
\hline A & 2.7 & 2.9 & 5.2 & 23.5 & 13.6 & 6.7 & 16.8 & 20.7 & 44.5 & ND & $7.7-10.2$ \\
\hline B & 2.4 & 2.0 & 3.7 & 29.0 & 9.6 & 3.0 & 11.7 & 24.4 & 29.4 & 64.5 & $9.1-12.8$ \\
\hline $\mathrm{C}$ & 2.6 & 2.6 & 5.2 & 34.0 & 20.3 & 6.9 & 21.3 & 26.8 & 55.5 & 69.9 & $12.0-18.8$ \\
\hline D & 2.5 & 4.5 & 12.6 & 43.4 & 14.7 & 5.0 & 16.2 & 22.3 & 46.8 & 45.2 & $19.4-23.8$ \\
\hline E & 1.9 & 4.5 & 10.0 & 37.5 & 15.3 & 4.4 & 12.2 & 19.1 & 50.9 & 59.4 & $19.4-25.1$ \\
\hline
\end{tabular}

A: Injection at $25 \mathrm{~V} / \mathrm{cm}$ for $10 \mathrm{~s}(6 \mathrm{nl})$. B: injection at $250 \mathrm{~V} / \mathrm{cm}$ for $10 \mathrm{~s}(60 \mathrm{nl})$. C: injection at $250 \mathrm{~V} / \mathrm{cm} \mathrm{for} 60 \mathrm{~s}(0.36 \mu l)$. D: injection at $250 \mathrm{~V} / \mathrm{cm}$ for $120 \mathrm{~s}(0.72 \mu \mathrm{l})$. E: injection at $250 \mathrm{~V} / \mathrm{cm}$ for $150 \mathrm{~s}(0.90 \mu \mathrm{l})$

were employed [13-24]. Although dispersion might occur during injection because the electrophoretic mobilities of DNA fragments in PBS were lower than that in TB buffer, stacking did not diminish because they migrated much slowly in PEO solution. Because chloride ions are much smaller, they should not stack as effectively as DNA did. Fig. 3 shows the separation of a $50 \mathrm{pg} / \mu \mathrm{l}$ DNA sample (containing markers $\mathrm{V}$ and VI) prepared in PBS after injecting at $250 \mathrm{~V} / \mathrm{cm}$ for $30 \mathrm{~s}$. The detection limit (based on the peak corresponding to the 57-bp) for the DNA sample was $25 \mathrm{pg} / \mu \mathrm{l}$. The sensitivity improvement was about 40 -fold compared to that injecting at 25 $\mathrm{V} / \mathrm{cm}$ for $10 \mathrm{~s}$. Because of high conductivity and relatively small electrophoretic mobilities of the DNA fragments in PBS, the maximum injection volume $(0.17 \mu \mathrm{l})$ was smaller than that in $\mathrm{TB}$ matrices $(0.90 \mu \mathrm{l})$. As we know, this is the largest volume of DNA sample in PBS demonstrated in CE without desalting procedures. Importantly to note that the peaks were generally sharper when injecting same amounts of DNA samples prepared in salts compared to those in TB matrices. This is most likely because DNA fragments became more compact under high-salt conditions [40].

\subsection{Stacking of GeneScan 1000 ROX}

To further test the feasibility of this new technique, we performed on-line concentration and separation of GeneScan 1000 ROX, which is a common DNA size ladder labeled with fluorophores, ROX (derivatives of carboxy-X-rhodamine). Fig. 4 depicts the separation of $1.54 \mu \mathrm{l}$ of 100 -fold diluted GeneScan 1000 ROX in $1.5 \%$ PEO solutions without containing $\mathrm{EtBr}$ using a $60-\mathrm{cm}$ capillary at 334
$\mathrm{V} / \mathrm{cm}$. To the best of our knowledge, $1.54 \mu \mathrm{l}$ is the largest volume injected for on-line concentration and separation of DNA samples in CE. Based on the intensity of the peak corresponding to the 55-bp fragment, the sensitivity enhancement was 265 -fold compared to that injected at $25 \mathrm{~V} / \mathrm{cm}$ for $10 \mathrm{~s}$. These results associated with those shown above clearly show the potential of this method for analysis of PCR products. Together with the results shown in Figs. 2A and $3 \mathrm{~A}$, we have proved that this method allows stacking DNA fragments whether prepared in buffers with high or low buffer capacity. Apparently, $\mathrm{pH}$ changes during concentration and separation should not play a major role in determining stacking efficiency.

\subsection{PCR products}

In order to detect small amounts of DNA samples, PCR amplification cycle is generally set up 20-30 cycles [41-43]. Longer amplification time and large amounts of primers and reagents are generally needed when performing more PCR cycles. To minimize these problems, a more sensitive detection method is generally needed. As shown above that our proposed method allows stacking large volumes of DNA in PBS without any sample pretreatment, we tested on-line concentration and separation of PCR products. Fig. 5A shows the electropherogram when injecting PCR products amplified after 17 cycles at 30 -cm height for $300 \mathrm{~s}(0.32 \mu \mathrm{l})$. To identify the two peaks shown in Fig. 5A, we spiked $\Phi X 174$ RF DNA-HaeIII digest into the PCR product and performed the analysis (result not shown). From the migration times for these two peaks and 194 and 234-bp fragments from the standard, we assigned 

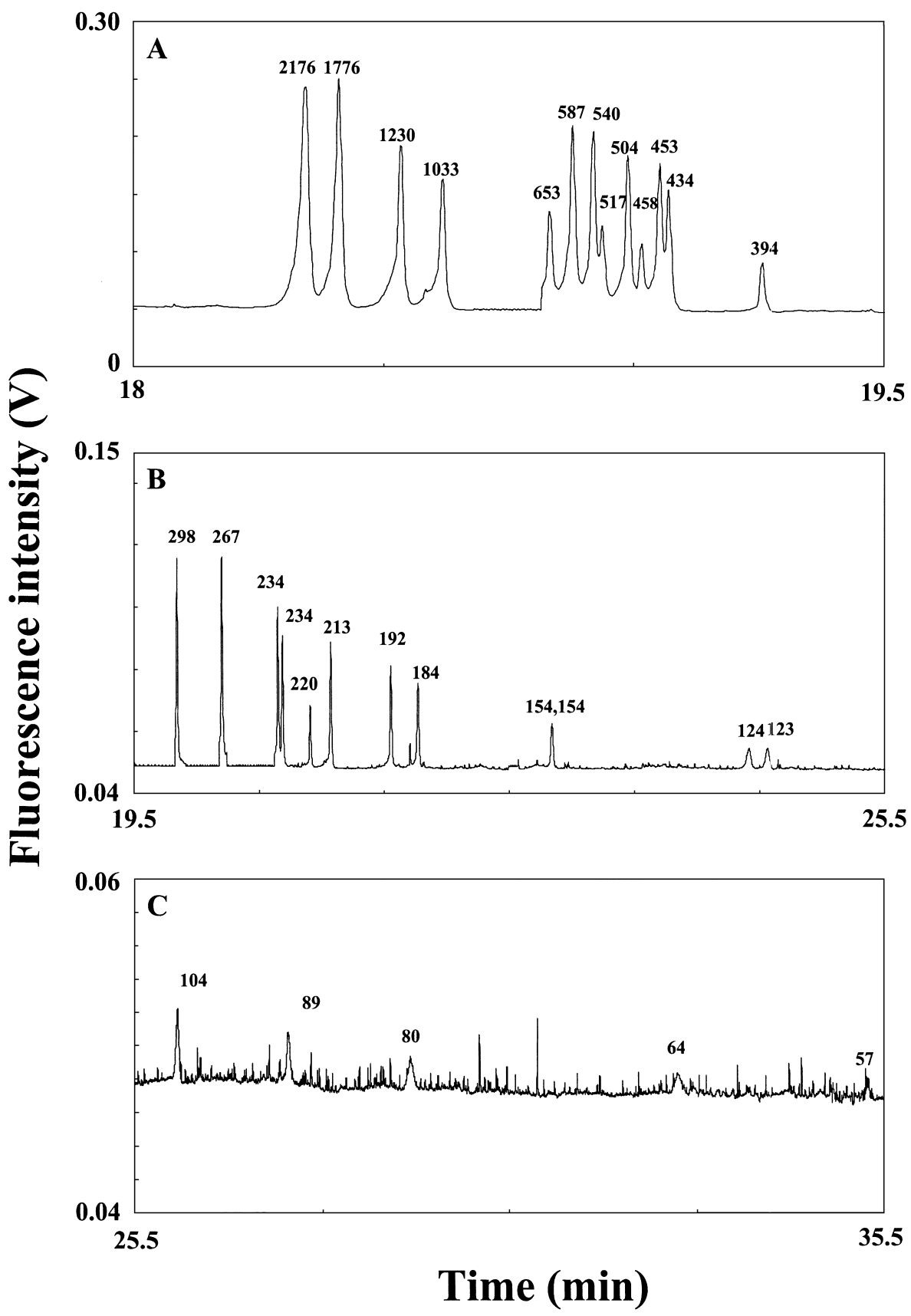

Fig. 3. Separation of $50 \mathrm{pg} / \mu \mathrm{l}$ DNA markers V and VI prepared in PBS in the presence of the EOF at $375 / \mathrm{V} / \mathrm{cm}$ using $1.5 \%$ PEO solutions containing $5 \mu \mathrm{g} / \mathrm{ml} \mathrm{EtBr}$. DNA injection was performed at $250 \mathrm{~V} / \mathrm{cm}$ for $30 \mathrm{~s}(0.17 \mu \mathrm{l})$. Panels A, B, and C represent electropherograms from 18 to $19.5,19.5$ to 25.5 , and 25.5 to $35.5 \mathrm{~min}$, respectively. Other conditions were as in Fig. 2. 


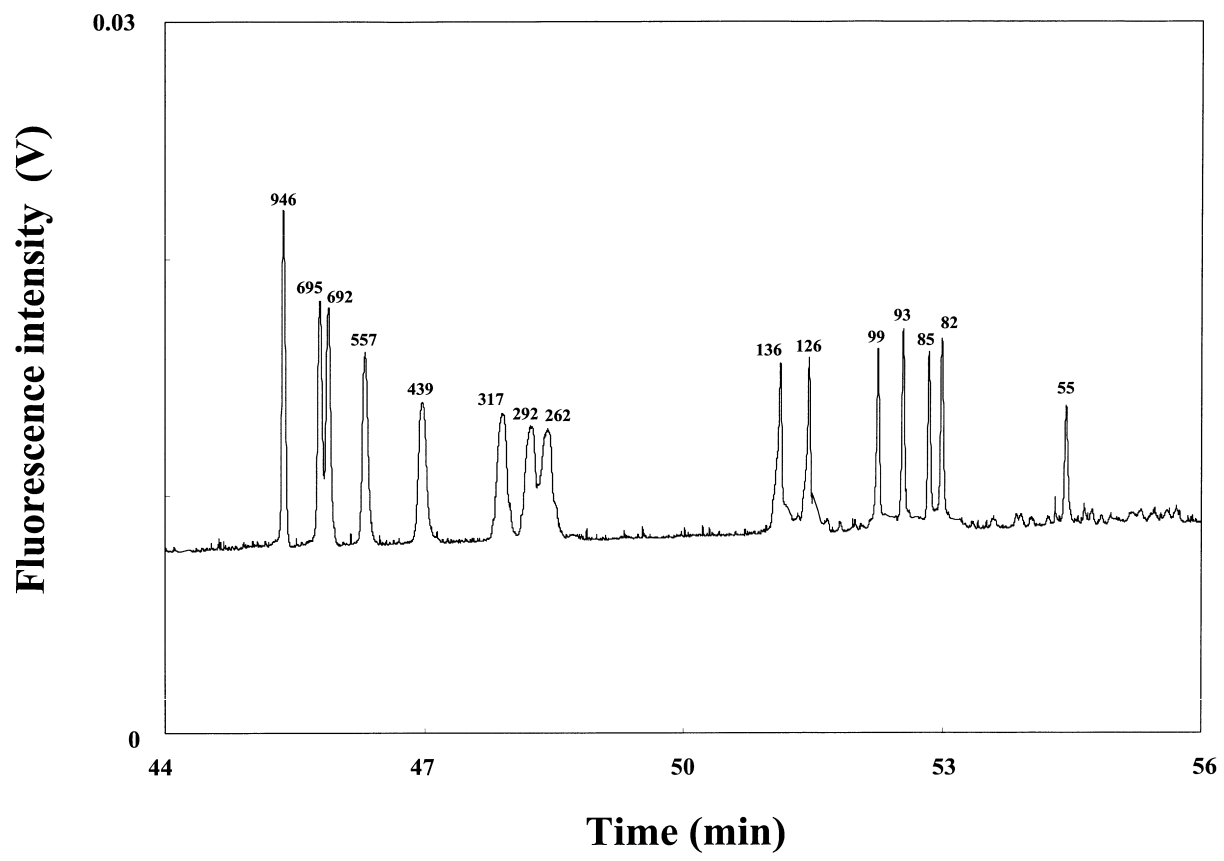

Fig. 4. Separation of a 100-fold diluted GeneScan 1000 ROX sample in the presence of the EOF at $334 \mathrm{~V} / \mathrm{cm}$ using $1.5 \%$ PEO prepared in $200 \mathrm{~m} M$ TB buffers, $\mathrm{pH} 9.0$. Capillary: $60 \mathrm{~cm}$ (50 cm effective length). DNA prepared in $25 \mathrm{~m} M$ TB buffers, $\mathrm{pH} 10.0$, was injected at 250 $\mathrm{V} / \mathrm{cm}$ for $300 \mathrm{~s}(1.54 \mu \mathrm{l})$.

these two peaks as corresponding to THO1 $(9,8)$ allele, containing 191 and 195-bp fragments. For comparison, PCR products amplified after 32 cycles were also injected at $30-\mathrm{cm}$ height for $10 \mathrm{~s}$ and were analyzed under the same condition. Unlike Fig. 5A, Fig. 5B shows two more peaks that are likely due to byproducts. Table 2 shows the comparison between these two methods. Clearly, the total analysis time was shortened from 119.5 to $91.3 \mathrm{~min}$. In addition, this method also provided better resolution. The result indicated the potential of this method for on-line analysis of PCR products [44].

\subsection{Comparison of this proposed method with existing techniques}

The comparison of this method and other on-line concentration techniques for the analysis of DNA in $\mathrm{CE}$ is summarized in Table 3. Because DNA stacks at the boundary between sample zone and PEO solution, on-line concentration of small analytes (in preparation) and/or macromolecules prepared in either low-conductivity or high-conductivity media are achieved by this proposed method. Another advantage of this approach over others is that a greater injection volume (up to $1.54 \mu \mathrm{l}$ ) can be analyzed in CE. This feature indicates that this method may be applied to recovery of DNA fragments, which can be used for further study in molecular biology such as gene expression [45]. Also note that this method allows the on-line concentration and separation of DNA samples in PBS (the concentration of $\mathrm{NaCl}$ is above $130 \mathrm{mM}$ ) and PCR products without desalting, implying that this approach should be suitable for analysis of different biological samples. Unlike other methods, resolution is not critically limited by injection length because DNA migrated against the EOF. More importantly, resolution, migration time and stacking efficiency can be further optimized by regulation of EOF, possibly through changes in buffer electrolytes, polymer species and concentration, and so on. Thus 


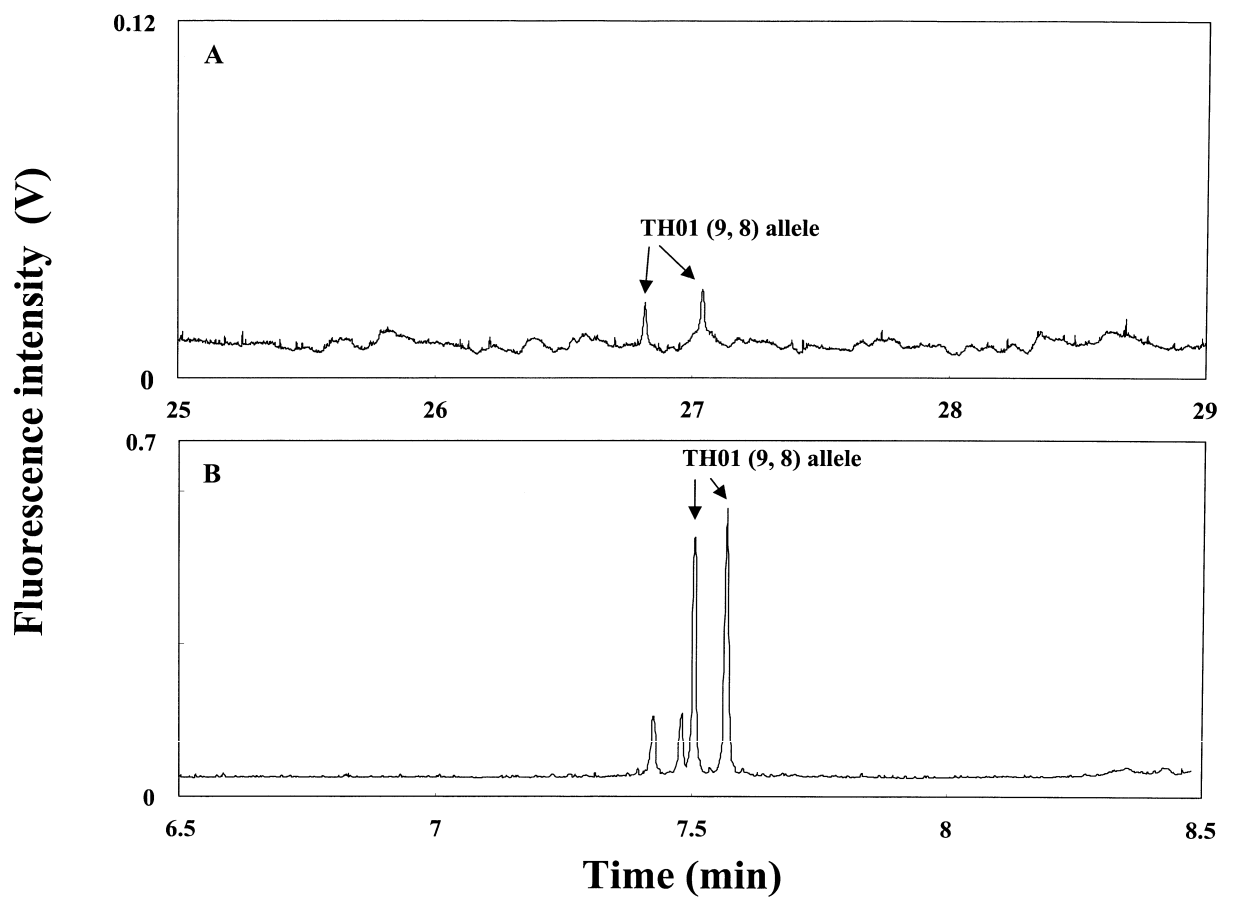

Fig. 5. Separation of PCR products. (A) PCR products amplified after 17 cycles were hydrodynamically injected at 30 -cm height for $300 \mathrm{~s}$ $(0.32 \mu 1)$. (B) PCR products amplified after 32 cycles were hydrodynamically injected at $30 \mathrm{~cm}$ for $10 \mathrm{~s}$. Other conditions as in Fig. 4.

we should be able to apply stepwise techniques for concentration of a number of analytes, such as DNA and proteins with significantly differential sizes.

\section{Conclusions}

The on-line concentration and separation of DNA samples prepared in low and high-conductivity media has been achieved in the presence of EOF. DNA stacking was caused by the difference in the

Table 2

Comparison of analysis of PCR products amplified by 17 and 32 cycles

\begin{tabular}{lll}
\hline & 32 Cycles & 17 Cycles \\
\hline PCR running time (min) & 112 & 59.5 \\
Injection time (s) & 10 & 300 \\
Separation time $(\min )$ & 7.6 & 27.1 \\
Total time (min) & 119.6 & 91.6 \\
Injection volume $(\mu \mathrm{l})$ & 0.01 & 0.32 \\
Peak area (\% RSD) $(n=4)$ & $250000(4.2)$ & $11000(1.9)$ \\
Resolution & 7.2 & 8.7 \\
\hline
\end{tabular}

mobility of the DNA fragments in the sample matrices and PEO. Because DNA samples were injected into the capillary filled with $400 \mathrm{~m} M$ TB buffer, sample bias is less serious using this method compared to conventional ones (capillary filled with polymer solutions). As a result, concentration of DNA in high salts was more effectively. We have also shown results of greater than 256-fold improvement in sensitivity, up to $1.54 \mu \mathrm{l}$ injection volume, and elimination of time-consuming preconcentration and desalting procedures for DNA analysis. By performing this method, the PCR amplification cycle was shortened to 17 cycles. As expected, we should be able to perform PCR amplification with small amounts of reagents and DNA sample, leading to less expense. As shown that concentration, migration time, and resolution can be optimized by regulation of EOF, we are now focusing on searching for more suitable polymer solutions and electrolytes, and developing multiple-step stacking techniques. With the ability to improve concentration efficiency and resolution, many problems in the analysis of biological and chemical samples may be overcome and 
Table 3

Comparison of on-line concentration techniques for DNA analysis

\begin{tabular}{|c|c|c|c|c|c|}
\hline Preconcentration mode & Separation buffer & Sample matrix & $\mathrm{EOF}$ & Injection volume & Ref. \\
\hline $\begin{array}{l}\text { Membrane-mediated }{ }^{\mathrm{a}} \\
\text { sample stacking }\end{array}$ & $1 \times \mathrm{TB}, \mathrm{pH} 8.3$ & $\begin{array}{l}83 \% \text { formamide } \\
\text { containing } 3.5 \mathrm{~m} M \text { EDTA }\end{array}$ & No & $1.0 \mu \mathrm{l}$ & {$[28]$} \\
\hline Isotachophoresis & $50 \mathrm{~m} M \mathrm{~TB}, \mathrm{pH} 8.3$ & $\begin{array}{l}50 \mathrm{~m} M \mathrm{KCl}, 10 \mathrm{~m} M \\
\text { Tris- } \mathrm{HCl} \text {, and } 1.5 \mathrm{~m} M \mathrm{MgCl}_{2}\end{array}$ & No & $0.7 \mu l$ & {$[15]$} \\
\hline \multirow[t]{2}{*}{ Field amplification } & $\begin{array}{l}100 \mathrm{~m} M \text { TB, } \mathrm{pH} 8.5 \\
50 \mathrm{~m} M \text { HEPES, } 60 \mathrm{~m} M \\
\text { borate, } \mathrm{pH} 8.1\end{array}$ & $\begin{array}{l}\text { Water } \\
\text { Water }\end{array}$ & $\begin{array}{l}\text { No } \\
\text { No }\end{array}$ & $\begin{array}{l}202 \mathrm{~V} / \mathrm{cm}, 1.5 \mathrm{~s} \\
0.5 \mu \mathrm{l}\end{array}$ & $\begin{array}{l}{[19]} \\
{[22]}\end{array}$ \\
\hline & $100 \mathrm{~m} M$ Tris-TAPS & Water & No & $91 \mathrm{~V} / \mathrm{cm}, 7 \mathrm{~s}$ & {$[20]$} \\
\hline Base stacking & $\begin{array}{l}50 \mathrm{~m} M \text { Tris- } \mathrm{HCl} \\
\mathrm{pH} 8.0\end{array}$ & $50 \mathrm{~m} M$ Tris $-\mathrm{HCl}$ & No & $50 \mathrm{~V} / \mathrm{cm}, 360 \mathrm{~s}$ & {$[27]$} \\
\hline Polymer stacking & $200 \mathrm{~m} M \mathrm{~TB}, \mathrm{pH} 9.0$ & $\begin{array}{l}5 \mathrm{~m} M \text { Tris }-\mathrm{HCl}, \mathrm{pH} 7.0 \\
5 \mathrm{~m} M \text { Tris- } \mathrm{HCl}, \mathrm{pH} 7.0 \\
\text { PBS } \\
25 \mathrm{~m} M \text { TB, } \mathrm{pH} 10.0\end{array}$ & $\begin{array}{l}\text { Yes } \\
\text { Yes } \\
\text { Yes } \\
\text { Yes }\end{array}$ & $\begin{array}{l}0.67 \mu l \\
0.9 \mu l \\
0.17 \mu l \\
1.54 \mu l\end{array}$ & $\begin{array}{l}{[35]} \\
\text { This work } \\
\text { This work } \\
\text { This work }\end{array}$ \\
\hline
\end{tabular}

\footnotetext{
${ }^{\text {a }}$ Thin slab-gel electrophoresis. HEPES, $N$-2-hydroxyethylpiperazine- $N$ '-2-ethanesulfonic acid, TAPS, $N$-tris(hydroxymethyl)methyl-3aminopropanesulfonic acid.
}

the role of $\mathrm{CE}$ in the analysis of biopolymers such as DNA and proteins is given a new significance.

\section{Acknowledgements}

This work was supported by the National Science Council of Taiwan under contract number NSC 892113-M002-062.

\section{References}

[1] V. Dolnik, M.J. Novotny, J. Microcol. Sep. 4 (1993) 515.

[2] M. Chiari, M. Nesi, P.G. Righetti, Electrophoresis 15 (1994) 616.

[3] E. Carrilho, M.C. Ruiz-Martinez, J. Berka, I. Smirnov, W. Goetzinger, A.W. Miller, D. Brady, B.L. Karger, Anal. Chem. 68 (1996) 3305.

[4] A.E. Barron, W.M. Sunada, H.W. Blanch, Electrophoresis 17 (1996) 744.

[5] Z. Mala, K. Kleparnik, P. Bocek, J. Chromatogr. A 853 (1999) 371.

[6] Y. Liu, W.G. Kuhr, Anal. Chem. 71 (1999) 1668.

[7] Y. Kim, M.D. Morris, Anal. Chem. 66 (1994) 1168.

[8] Y. Fang, J.Z. Zhang, J.Y. Hou, H. Lu, N.J. Dovichi, Electrophoresis 17 (1996) 1436.

[9] C.V. Owens, Y.Y. Davidson, S. Kar, S.A. Soper, Anal. Chem. 69 (1997) 1256

[10] S.M. Clark, R.A. Mathies, Anal. Chem. 69 (1997) 1355.
[11] B. B Haab, R.A. Mathies, Appl. Spectrosc. 51 (1997) 1579.

[12] A.V. Orden, H. Cai, P.M. Goodwin, R.A. Keller, Anal. Chem. 71 (1999) 2108.

[13] S. Auriola, L. Jaaskelainen, M. Regina, A. Urtti, Anal. Chem. 68 (1996) 3907.

[14] I. Barme, G.J.M. Bruin, A. Paulus, M. Ehrat, Electrophoresis 19 (1998) 1445.

[15] A. Guttman, E. Szoko, J. Chromatogr. A 744 (1996) 321.

[16] M.J. van der Schans, J.L. Beckers, M.C. Molling, F.M. Everaerts, J. Chromatogr. A 717 (1995) 139.

[17] R.L. Chien, J.C. Helmer, Anal. Chem. 63 (1991) 1354.

[18] R.L. Chien, D.S. Burgi, Anal. Chem. 64 (1992) 489A.

[19] A. Guttman, H.E. Schwartz, Anal. Chem. 67 (1995) 2279.

[20] K. Kleparnik, Z. Mala, P. Bocek, J. Chromatogr. A 772 (1997) 243.

[21] A. Beckmann, F. Getbrhardt, B.H. Brandt, J. Chromatogr. B 710 (1998) 75.

[22] Z.K. Shihabi, J. Chromatogr. A 853 (1999) 349.

[23] J.M. Butler, B.R. McCord, J.M. Jung, M.R. Wilson, B. Budowle, R.O. Allen, J. Chromatogr. B 658 (1994) 271.

[24] J.L. Beckers, P. Bocek, Electrophoresis 21 (2000) 2747.

[25] H. Swerdlow, R. Gesteland, Nucleic Acids Res. 18 (1990) 1415.

[26] O. Salas-Solano, M.C. Ruiz-Martinez, E. Carrilho, L. Kotler, B.L. Karger, Anal. Chem. 70 (1998) 1528.

[27] Y. Xiong, S.R. Park, H. Swerdlow, Anal. Chem. 70 (1998) 3605.

[28] A. Guttman, Anal. Chem. 71 (1999) 3598.

[29] N.C. Stellwagen, C. Gelfi, P.G. Righetti, Biopolymers 43 (1997) 687.

[30] S. Mathur, B.M. Moudgil, J. Colloid Interface Sci. 196 (1997) 92.

[31] H.-S. Chen, H.-T. Chang, Electrophoresis 19 (1998) 3149.

[32] H.-S. Chen, H.-T. Chang, Anal. Chem. 71 (1999) 2033. 
[33] H.-S. Chen, H.-T. Chang, J. Chromatogr. A 853 (1999) 337.

[34] W.-L. Tseng, M.-M. Hsieh, S.-J. Wang, H.-T. Chang, J. Chromatogr. A 894 (2000) 219.

[35] M.-M. Hsieh, W.-L. Tseng, H.-T. Chang, Electrophoresis 21 (2000) 2904.

[36] W.-L. Tseng, H.-T. Chang, Anal. Chem. 72 (2000) 4805.

[37] H.-T. Chang, E.S. Yeung, J. Chromatogr. 608 (1992) 65.

[38] H.E. Schwartz, K. Ulfelder, F.J. Sunzeri, M.P. Busch, R.G. Brownlee, J. Chromatogr. 559 (1991) 267.

[39] M.C. Ruiz-Martinez, O. Salas-Solano, E. Carrilho, L. Kotler, B.L. Karger, Anal. Chem. 70 (1998) 1516.

[40] N. Borochov, H. Eisenberg, Macromolecules 27 (1994) 1440.
[41] Y. Wang, S.-C. Hung, J.F. Linn, G. Steiner, A.N. Glazer, D. Sidransky, R.A. Mathies, Electrophoresis 18 (1997) 1742.

[42] W. Goodwin, A. Linacre, P. Vanezis, Electrophoresis 20 (1999) 1707.

[43] U. Ricci, I. Sani, S. Guarducci, C. Biondi, S. Pelagatti, V. Lazzerini, A. Brusaferri, M. Lapini, E. Andreucci, L. Giunti, M.L.G. Uzielli, Electrophoresis 21 (2000) 3564.

[44] J. Khandurina, T.E. McKnight, S.C. Jacobson, L.C. Waters, R.S. Foote, J.M. Ramsey, Anal. Chem. 72 (2000) 2995.

[45] J. Khan, L.H. Saal, M.L. Bittner, Y. Chen, J.M. Trent, P.S. Meltzer, Electrophoresis 20 (1999) 223. 